\title{
In Vitro Biocompatibility of MC3T3-E1 Osteoblast-like Cells on Arg-Gly-Asp Acid Peptides Immobilized Graphite-like Carbon Coating on Carbon/Carbon Composites
}

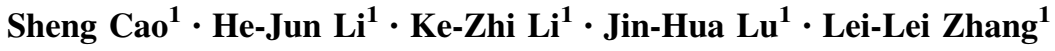

Received: 2 September 2016/Revised: 21 October 2016/Published online: 13 February 2017

(C) The Chinese Society for Metals and Springer-Verlag Berlin Heidelberg 2017

\begin{abstract}
Carbon/carbon (C/C) composites were deposited with graphite-like carbon (GLC) coating, and then, Arg-GlyAsp acid (RGD) peptides were successfully immobilized onto the functionalized GLC coating. GLC coating was utilized to prevent carbon particles releasing and create a uniform surface condition for $\mathrm{C} / \mathrm{C}$ composites. RGD peptides were utilized to improve biocompatibility of GLC coating. Surface chemical characterizations of functionalized GLC coating were detected by contact angle measurement, X-ray photoelectron spectroscopy and Raman spectra. Optical morphology of GLC coatings was observed by confocal laser scanning microscopy. In vitro biological performance was determined using samples seeded with MC3T3-E1 osteoblast-like cells and cultured for 1 week. Surface characterizations and morphological analysis indicated that $\mathrm{C} / \mathrm{C}$ composites were covered by a dense and uniform GLC coating. Contact angle of GLC coating was reduced to $27.2^{\circ}$ when it was functionalized by $\mathrm{H}_{2} \mathrm{O}_{2}$ oxidation at $40{ }^{\circ} \mathrm{C}$ for $1 \mathrm{~h}$. In vitro cytological test showed that the RGD peptides immobilized GLC coating had a significant improvement in biocompatibility. It was suggested that RGD peptides provided GLC coating with a bioactive surface to improve cell adhesion and proliferation on C/C composites.
\end{abstract}

KEY WORDS: MC3T3-E1 osteoblast-like cells; Carbon/carbon composites; Graphite-like carbon (GLC) coating; Arg-Gly-Asp acid (RGD) peptides; Surface modification

\section{Introduction}

Carbon materials have been proved as good candidates for a wide variety of biomedical applications [1, 2]. Graphite-like carbon (GLC) is one form of amorphous carbons with non-toxic effect on living organisms. It could be deposited on hip joints, artificial hearts and stents due to its bioinert character, high chemical inertness, high hardness, excellent hemocompatibility and favorable tribological properties [3, 4]. Rodil et al. had

Available online at http://link.springer.com/journal/40195

He-Jun Li

lihejun@nwpu.edu.cn

1 State Key Laboratory of Solidification Processing, Northwestern Polytechnical University, Xi'an 710072, China investigated graphite-like amorphous carbon coating as a bioactive coating for medical stainless steel implants by culturing osteoblasts on its surface in vitro [5, 6]. The short-term cellular adhesion and proliferation tests demonstrated that the coating had good biocompatibility and the medium-term test indicated the formation of calcified matrix with the expression of bone sialoprotein and alkaline phosphatase. They considered graphite-like amorphous carbon as a potential bioactive coating candidate for bone inducement.

Carbon/carbon (C/C) composites are often used as hightemperature structural materials for space applications. They are also considered to be potential orthopedics materials due to their favorable mechanical properties and good biocompatibility with blood and tissues [7, 8]. Though $\mathrm{C} / \mathrm{C}$ composites have been studied as bone implants for many years, carbon debris releasing to tissues during and after a bone replacement surgery was still a 
problem. This issue was caused by the excessive micromovements at the interface of implants and tissue, if the ingrown bone is separated from the implant by an intervening soft tissue layer [5]. To eliminate this problem, several kinds of films and coatings have been applied on the surface of $\mathrm{C} / \mathrm{C}$ composites, such as titanium films and calcium phosphate coatings. However, these coatings are still far from practical use. Amorphous carbon coating also could be prepared on $\mathrm{C} / \mathrm{C}$ composites. High hardness and favorable tribological properties, which belong to the amorphous carbon coating, were obtained by $\mathrm{C} / \mathrm{C}$ composites [9]. As the amorphous carbon coating is applied, two advantages appear. First, galvanic corrosion, stress corrosion cracking and degradation would not occur, when compared with metal and ceramic coating. Second, the composite sample is still pure carbon material and no other element is introduced.

When $\mathrm{C} / \mathrm{C}$ composites are used as an orthopedic implant, each part may be in contact with different tissues, such as, bone, cartilage, blood vessels and muscle. The functions of corrosion resistance, lubrication, bioactivity and osteoinduction may be needed in different contact areas. However, amorphous carbon coating could only satisfy the functions of corrosion resistance and lubrication. Bioactivity and osteoinduction requirements could not be satisfied simultaneously. Therefore, to overcome these problems, Arg-Gly-Asp acid (RGD) peptides could be grafted onto the surface of amorphous carbon coating [10]. RGD peptides are small-chain amino acid sequences, which could improve the cellular adhesion [11]. It is usually immobilized onto the surface of metal implants and polymer scaffolds to improve their bioactive. Researches demonstrated RGD peptides have osteoinduction ability during long-term study [12]. RGD peptides were usually grafted onto the surface of implants by UV, silane coupling agent and chemical coupling agent [13-16]. In nano-carbon material areas, researchers had immobilized RGD peptides on functionalized grapheme and nanotubes to find their potentiality in biomedical field $[17,18]$. Nano-carbon materials were oxidized and oxygen-containing groups were formed, then biomolecules were immobilized onto nano-carbon materials [19]. These oxidized methods used for functionalizing nano-carbon materials also could be used. Unfortunately, most oxidation methods for nano-carbon materials were not suitable for $\mathrm{C} / \mathrm{C}$ composite, because the structure of $\mathrm{C} / \mathrm{C}$ composite could be damaged after strong oxidation [20]. In addition, some graphitized nano-materials, such as grapheme nanoparticles, showed some cyto- and genotoxicities against the mesenchymal stem cells [21-23]. Therefore, a suitable oxidized method should be used to functionalize the amorphous carbon coating. At the same time, the structural damage of amorphous carbon coating also should be avoided. In our previous work, a density collagen film was successfully prepared on $\mathrm{H}_{2} \mathrm{O}_{2}$ modified $\mathrm{C} / \mathrm{C}$ composites [24]. Experimental results showed that $\mathrm{H}_{2} \mathrm{O}_{2}$ modification has no cytotoxicity. Therefore, this modification may be also suitable for GLC coating to obtain a functional surface.

In this paper, a GLC coating was prepared on $\mathrm{C} / \mathrm{C}$ composites and marked as GLC-C/C composites. A $\mathrm{H}_{2} \mathrm{O}_{2}$ modification was used to functionalize the surface of GLC$\mathrm{C} / \mathrm{C}$ composites. Then, RGD peptides were immobilized onto the functionalized surface of GLC-C/C composites. Surface characterizations of C/C, GLC-C/C and $\mathrm{H}_{2} \mathrm{O}_{2}$ modified GLC-C/C samples were assessed. In vitro culture of MC3T3-E1 osteoblast-like cells on RGD peptides immobilized GLC-C/C samples was also investigated. It is anticipated that this RGD peptides immobilized GLC-C/C composites would potentially result in a successful bioactivity enhancement on $\mathrm{C} / \mathrm{C}$ composites for bone replacement.

\section{Materials and Methods}

\subsection{C/C Composites}

$\mathrm{C} / \mathrm{C}$ composites were prepared by chemical vapor infiltration (CVI) process in our laboratory. Carbon preform was carbon fiber needled felts and the carbon source used for infiltration was natural gas [25]. Samples were cut into $15 \mathrm{~mm} \times 10 \mathrm{~mm} \times 3 \mathrm{~mm}$, and their densities were between 1.70 and $1.75 \mathrm{~g} \mathrm{~cm}^{-3}$. Prior to GLC coating preparation, each sample was polished to $15 \mathrm{~mm} \times 10 \mathrm{~mm}$ $\times 2 \mathrm{~mm}$ with $\mathrm{SiC}$ sandpapers in the number sequence of 400, 800, 1200 and 1500. After that, they were rinsed with distilled water, cleaned ultrasonically in acetone and dried in a vacuum environment.

\subsection{GLC Coating Preparation}

The GLC coating was deposited on C/C composites by an unbalance magnetron sputtering technique (Teer Coating, U.K.) $[26,27]$. Two magnetron graphite targets were fitted on the inside of the vacuum chamber and focused on the sample holder. A base pressure of $3 \times 10^{-5}$ Torr was attained in the chamber with a turbo molecular pumping system. Once the vacuum level was reached, the substrate surfaces were first cleaned for $15 \mathrm{~min}$ by $\mathrm{Ar}^{+}$ion sputtering. Particular deposition conditions of GLC coating were given as follows: The applied DC current on the graphite target was $0.3 \mathrm{~A}$. The deposition bias voltage was $-90 \mathrm{~V}$. The gas flow rate of Ar was $20 \mathrm{sccm}$. The deposition pressure was $1 \times 10^{-3}$ Torr, and the deposition time was $2.5 \mathrm{~h}$. 


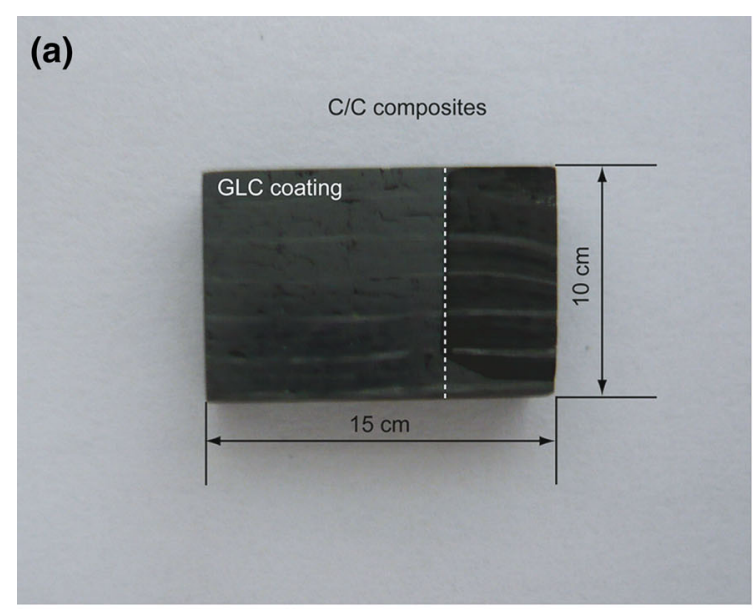

(b)

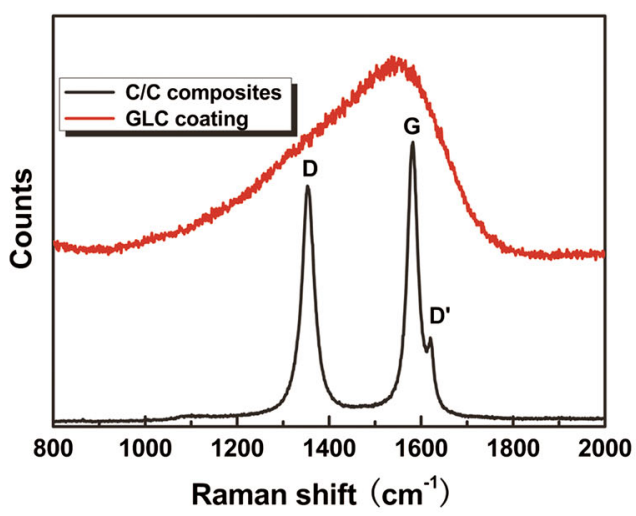

(c)

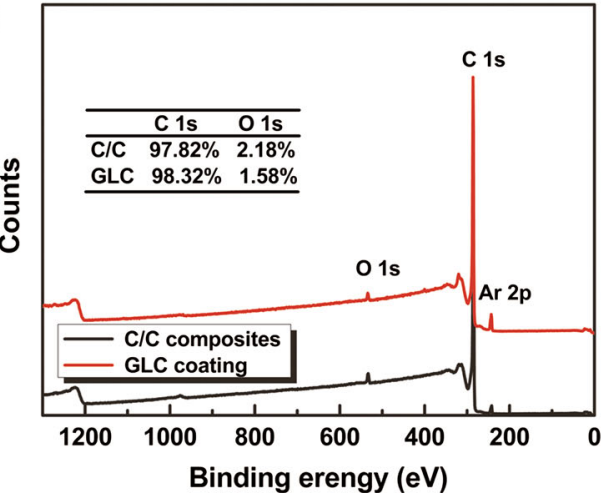

(d)

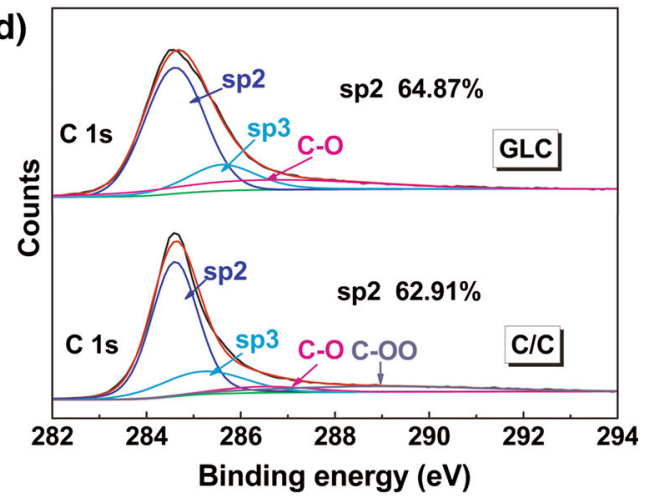

Fig. 1 GLC coating on C/C composites: a macrophotograph of C/C composites with GLC coating, b Raman spectra of GLC coating and C/C substrate, $\mathbf{c}$ XPS spectra of GLC coating and C/C substrate, $\mathbf{d}$ high-resolution C1s spectra of GLC coating and C/C substrate

\subsection{Surface Modification of GLC-C/C}

Each GLC-C/C sample was cut into $10 \mathrm{~mm} \times 10 \mathrm{~mm} \times$ $2 \mathrm{~mm}$ to remove the uncoated part and then immersed in $50 \mathrm{~mL} 30 \% \mathrm{H}_{2} \mathrm{O}_{2}$ solution, which had been maintained at $30-80{ }^{\circ} \mathrm{C}$ in a thermostat water bath. The oxidation time was $1 \mathrm{~h}$. These samples were washed by deionized water for at least three times and dried in a vacuum environment, after they were taken out from $\mathrm{H}_{2} \mathrm{O}_{2}$ solution. These samples were all sterilized by an autoclave.

\subsection{RGD Peptides and its Immobilizing}

RGD peptides (A101724, Aladdin, USA) were purchased from LSBIO Company (Xi' an, China). RGD peptides were dissolved in ultrapure water and a $10 \mathrm{ng} \mathrm{mL}^{-1}$ RGD solution was obtained; then, the solution was sterilized by using a $0.2 \mu \mathrm{m}$ syringe filter (PALL Life Science, USA). The RGD solution was stored at $4{ }^{\circ} \mathrm{C}$.
Four modified specimens oxidized at $30^{\circ} \mathrm{C}$ for $1 \mathrm{~h}$ were placed in each well of a 6-well cell culture plate, and the RGD solution was poured into the wells with $12 \mathrm{~mm}$ liquid depths above the surface of the substrates. The culture plate was maintained at $4{ }^{\circ} \mathrm{C}$ for $48 \mathrm{~h}$ and then dried in a drying cabinet [12]. The dried samples were immersed in a $30 \mathrm{~mol} / \mathrm{L}$ carbodiimide/N-hydroxysuccinimide (EDC/ NHS) cross-linking solution and maintained at $4{ }^{\circ} \mathrm{C}$ for $4 \mathrm{~h}$. At last, all samples were washed with deionized water and also dried in a drying cabinet.

\subsection{Surface Characterization}

The wettability of $\mathrm{H}_{2} \mathrm{O}_{2}$ modified and unmodified GLC-C/ $\mathrm{C}$ specimens was investigated by using an optical contact angle meter (DataPhysics OCA20, Germany), and the contact medium is deionized water. The chemical states of the atoms in the surface of untreated and treated GLC-C/C specimens were investigated by using a Thermo Scientific K-Alpha X-ray photoelectron spectroscopy (XPS) 

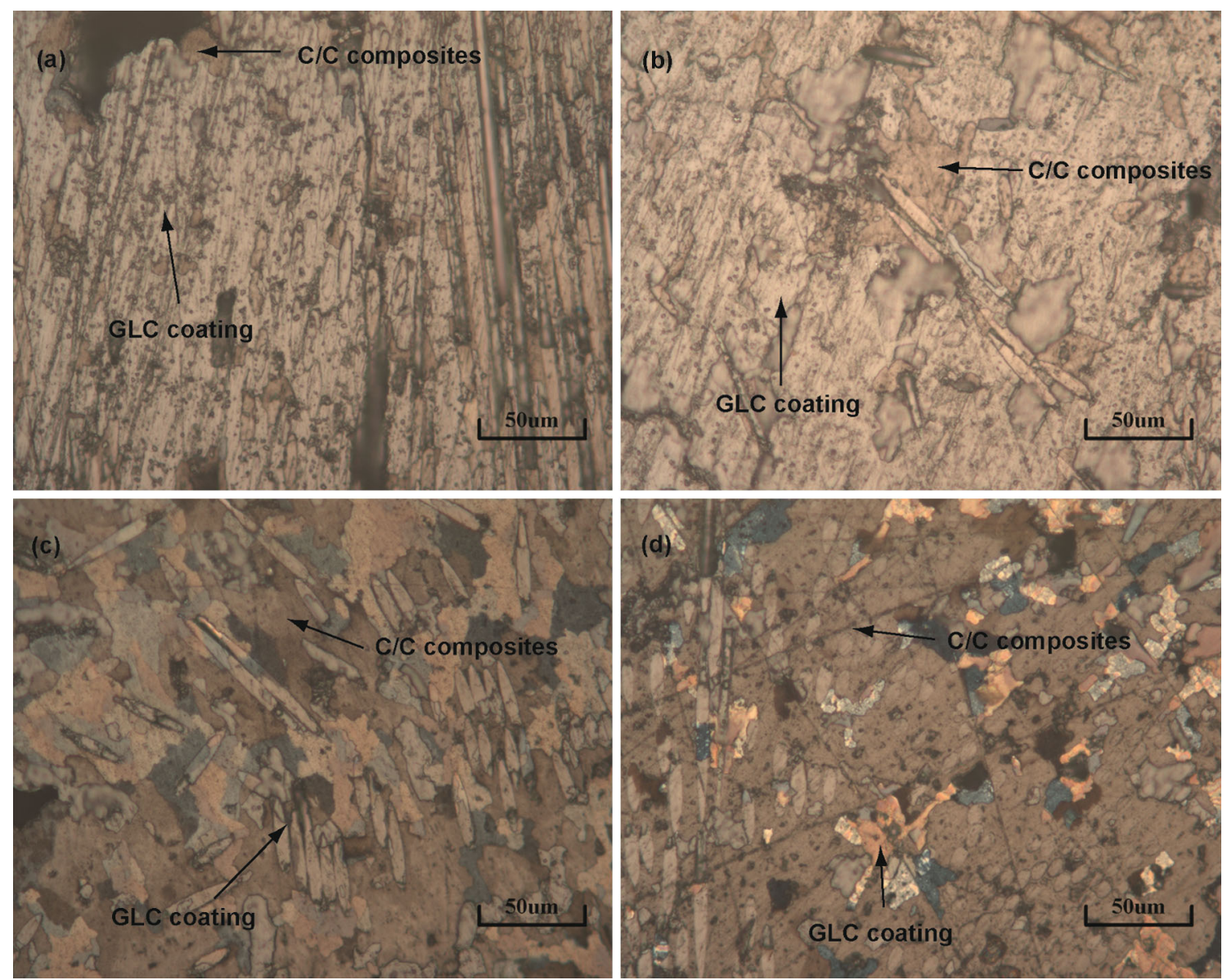

Fig. 2 Morphology changes in GLC coating at different oxidation temperatures: a $30^{\circ} \mathrm{C}$, b $50{ }^{\circ} \mathrm{C}, \mathbf{c} 60^{\circ} \mathrm{C}, \mathbf{d} 80^{\circ} \mathrm{C}$

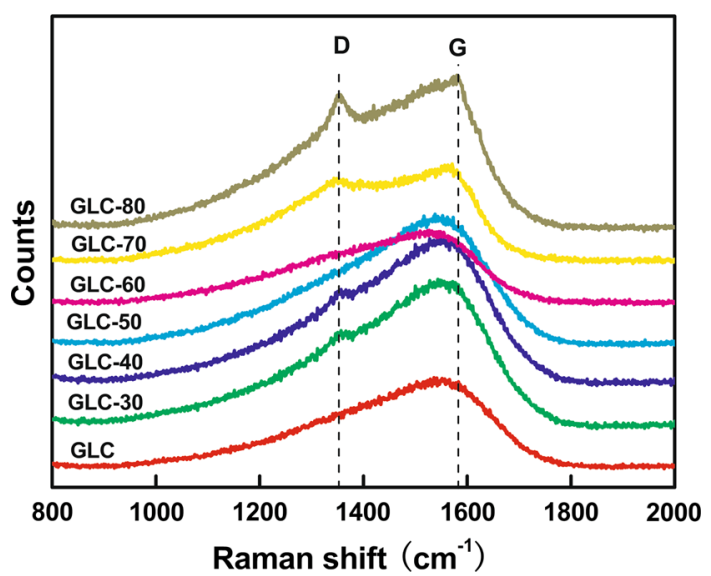

Fig. 3 Change trend of Raman spectra of GLC coatings at different oxidation temperatures

spectrometer (Thermo Scientific K-Alpha, USA). Charging correction during the analysis was accomplished by shifting the main $\mathrm{C}-\mathrm{C}$ peak to $284.6 \mathrm{eV}$. Raman spectroscopy was performed with a Renishan InVia system using a
$514 \mathrm{~nm}$ Ar laser. The laser beam was focused on the sample with a $50 \times$ objective lens. The optical morphologies of GLC coatings on $\mathrm{C} / \mathrm{C}$ substrates were measured by using a confocal laser scanning microscope (CLSM, Optelics C130, Lasertec Corp., Japan).

\subsection{Cell Culture and In Vitro Evaluation}

Samples with or without RGD peptides were all sterilized by epoxy ethane for cell culture. MC3T3-E1 osteoblastlike cells were obtained from Shanghai Institutes for Biological Science (SIBS) of Chinese Academy of Science (CAS). The cells were cultured in MEM- $\alpha$ medium containing $10 \%$ fetal bovine serum (FBS). After reaching $80 \%$ of confluence, the adherent cells were washed, trypsinized, counted and re-suspended to seed on the specimens. Each sample was put into one well of a 24-well cell culture plate. All the samples were covered with $700 \mu \mathrm{L}$ cell suspension, whose cellular concentration was $2 \times 10^{4} \mathrm{~mL}^{-1}$ in the medium (MEM- $\alpha$ with $10 \%$ FBS), and then incubated at $37{ }^{\circ} \mathrm{C}$ for 1 week. The 


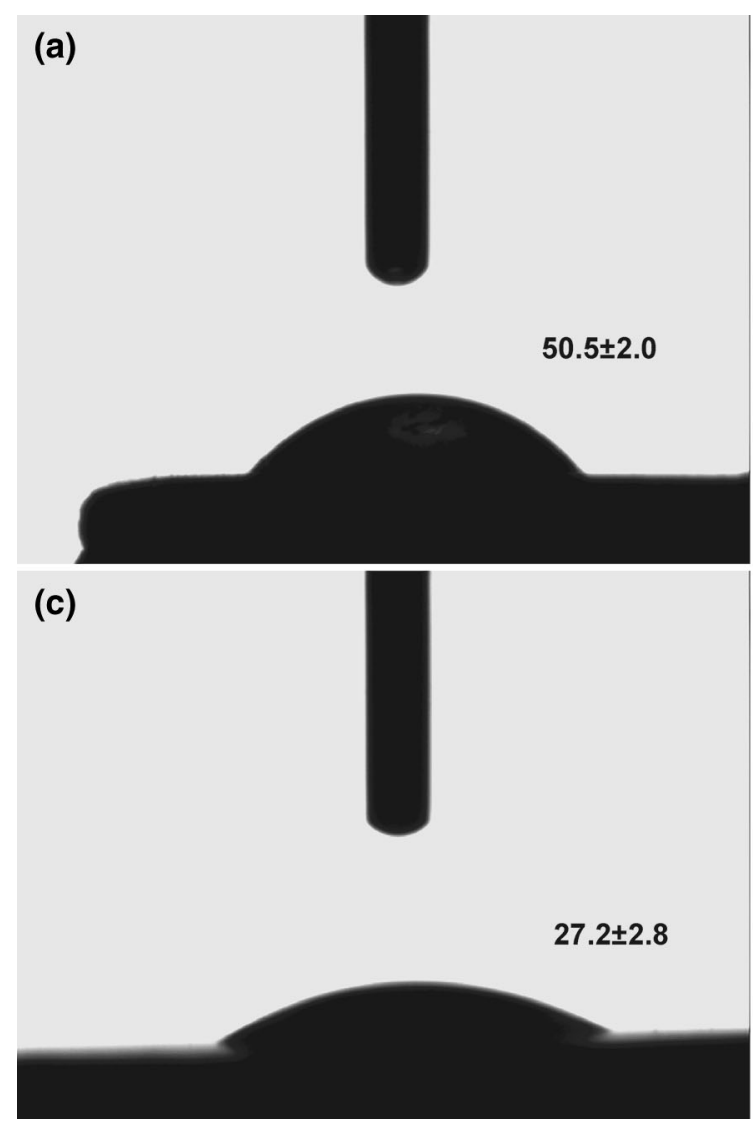

(b)
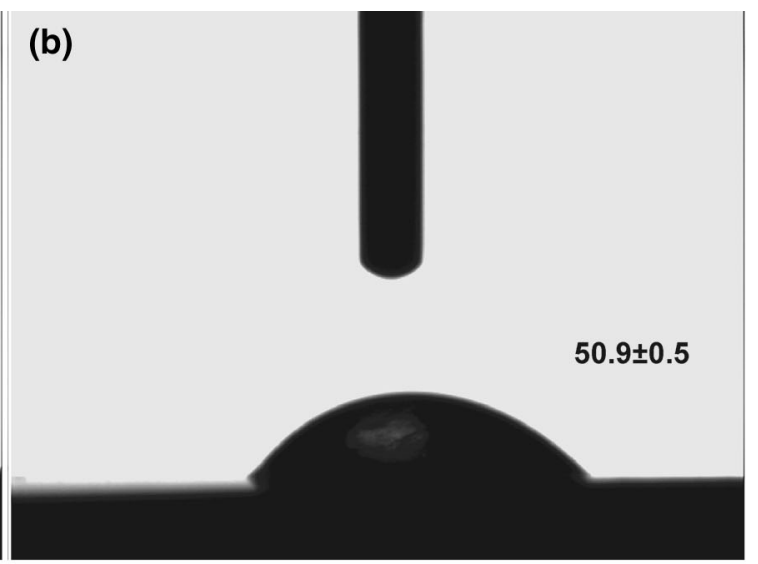

(d)
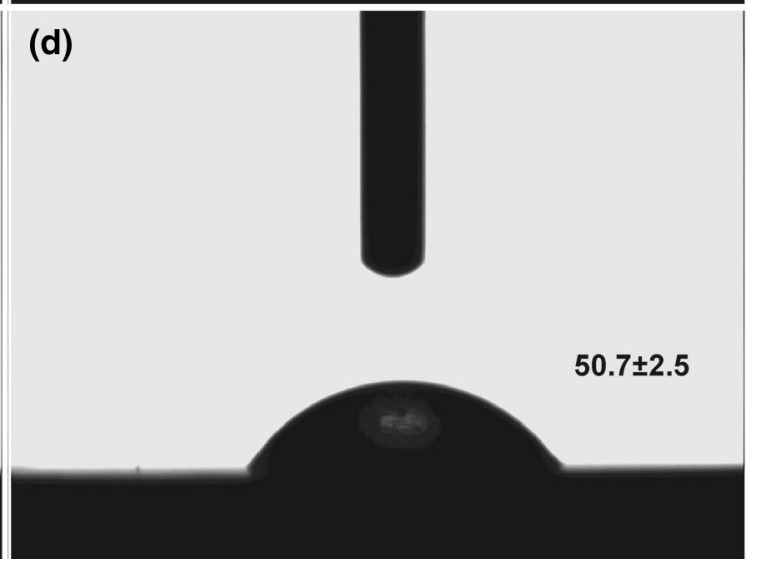

Fig. 4 Contact angles of GLC coatings at different oxidation temperatures: a untreated, b $30{ }^{\circ} \mathrm{C}, \mathbf{c} 40^{\circ} \mathrm{C}$, d $50{ }^{\circ} \mathrm{C}$

(a)

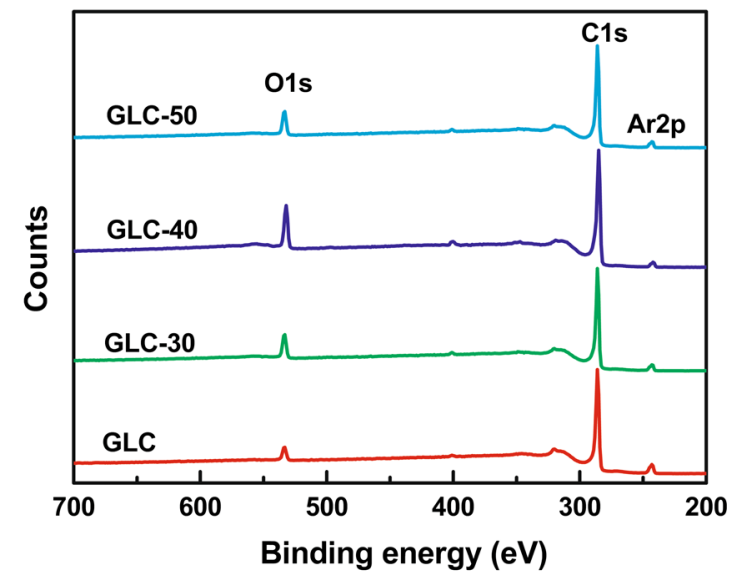

(b)

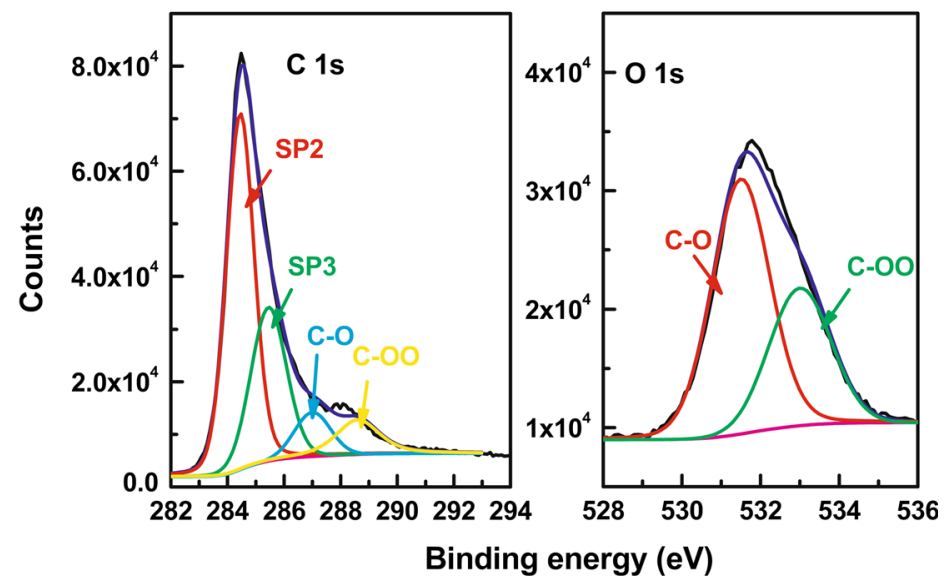

Fig. 5 XPS spectra of GLC coatings at different oxidation temperatures: a full XPS spectra, b high-resolution C1s and O1s spectra of GLC coating after oxidation at $40{ }^{\circ} \mathrm{C}$

specimens were evaluated at the 1st, 3rd, 5th and 7th day to determine the cell adhesion and proliferation, respectively.

In the cell proliferation test, samples were evaluated for 1 week. The samples evaluated were moved into a new empty 24-well culture plate and then filled with $900 \mu \mathrm{L}$ new medium and $100 \mu \mathrm{L}$ 3-(4,5-dimethyldiazol-2-yl)-2,5diphenyl tetrazolium bromide (MTT, Amresco, USA) solution $\left(5 \mathrm{mg} \mathrm{mL}^{-1}\right)$. The mixture was incubated for $4 \mathrm{~h}$ at $37^{\circ} \mathrm{C}$ and removed. After that, $1 \mathrm{~mL}$ dimethyl sulfoxide 


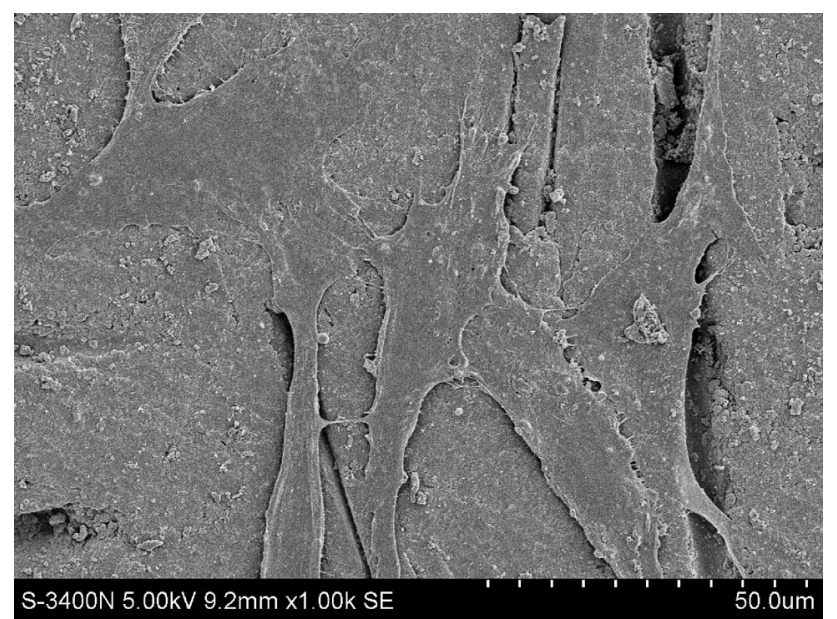

Fig. 6 Cellular morphology of MC3T3-E1 osteoblast-like cells on the modified GLC coating

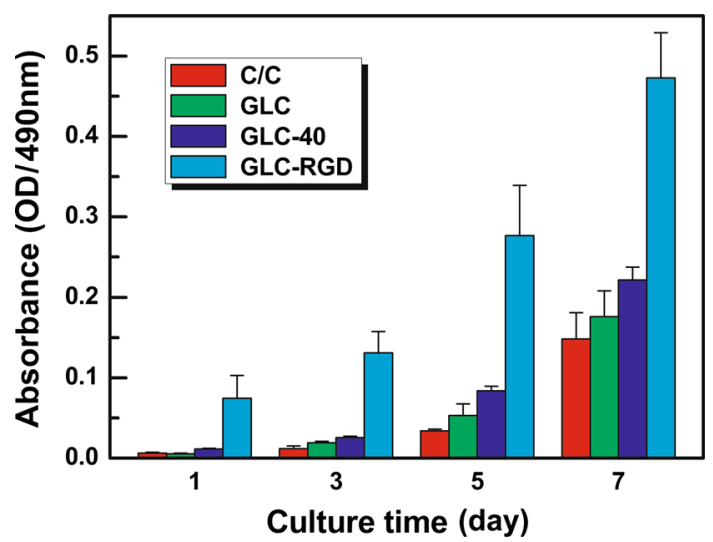

Fig. 7 In vitro cell adhesion and proliferation of ME3T3-E1 osteoblast-like cells on C/C, GLC, GLC-40 and GLC-RGD specimens

(DMSO, Amresco, USA) was added. The plate was shaken for 15 min, and 200- $\mu$ L DMSO was moved into a new well of a 96-well cell culture plate for absorbance detection at $490 \mathrm{~nm}$ by a microplate reader (Bio-Tek Instruments, USA) [24].

\subsection{Cellular Morphology Observations}

Samples with cells after 24-h culture were washed with phosphate buffer solution (PBS) and fixed by glutaraldehyde. After acetonitrile replacement, vacuum drying and gold sputter coating, samples with cells were examined by SEM [28].

\subsection{Statistical Analysis}

Statistical analysis was performed by a statistical software package SPSS 13.0. The statistical differences were calculated using Student's $t$ test.

\section{Results}

\subsection{GLC Coating on C/C Composites}

Figure 1a shows a macrophotograph of one $\mathrm{C} / \mathrm{C}$ substrate after the deposition of GLC coating using magnetron sputtering. Two-third surface area of this sample was gray and covered with a density GLC coating. In contrast, the remaining one-third surface was black without GLC coating because of the block by clamping holder. Raman spectra indicated that carbon microcrystalline structure on the surface of C/C substrate and GLC coating was completely different. Sharply D and G characteristic peaks of $\mathrm{C} / \mathrm{C}$ composites replaced by one broad composed characteristic peak (Fig. 1b). XPS data could not significantly distinguish their difference (Fig. 1c). In addition, the highresolution spectra of $\mathrm{C} 1 \mathrm{~s}$ showed that most of carbon atoms in GLC coating were in sp2 bonding type and their proportion was similar to that of $\mathrm{C} / \mathrm{C}$ composites (Fig. 1d).

\subsection{Oxidized GLC Coatings}

Figure 2 shows high-resolution optical morphologies of GLC coating after $\mathrm{H}_{2} \mathrm{O}_{2}$ modification, with the increase in oxidation temperature. In Fig. 2a, GLC coating still completely covered the $\mathrm{C} / \mathrm{C}$ substrate when the oxidation temperature was $30^{\circ} \mathrm{C}$. Figure $2 \mathrm{~b}$ shows that $\mathrm{C} / \mathrm{C}$ substrate was exposed in several areas when the oxidation temperature increased to $50{ }^{\circ} \mathrm{C}$. As the temperature increased to $60{ }^{\circ} \mathrm{C}$, the exposed areas of $\mathrm{C} / \mathrm{C}$ substrate had remarkable expansion with the peeling of GLC coating (Fig. 2c). Meanwhile, a variety of colors appeared on the GLC coating, under optical observation. In Fig. 2d, only small areas were still covered by GLC coating with multicolor, when the oxidation temperature increased to $80{ }^{\circ} \mathrm{C}$. Raman spectra were used to check these oxidized GLC coatings (Fig. 3) and then compared with the untreated GLC coating. As the oxidation temperature increased, the spectra of the modified GLC coatings were no longer smooth. Correspondingly, $\mathrm{D}$ and $\mathrm{G}$ characteristic peaks of $\mathrm{C} / \mathrm{C}$ composites were observed and their peak intensities were gradually increased.

\subsection{Suitable Oxidation Temperature of GLC Coating for Immobilizing}

Three groups of modified GLC coatings were chosen for contact angle measurement and XPS test to determine a suitable modification parameter. According to the results shown in Fig. 4, the surface wettability of modified GLC coatings at 30 and $50{ }^{\circ} \mathrm{C}$ did not exhibit any substantive change when compared with those of the untreated GLC 
coating (Fig. 4a, b, d). When the oxidation temperature was $40{ }^{\circ} \mathrm{C}$, the wettability of modified GLC coating had a significant improvement and the contact angle was decreased from $50.5^{\circ}$ to $27.2^{\circ}$ (Fig. 4c). According to XPS analysis as shown in Fig. 5, the surface concentration of oxygen element on the modified GLC coating at $40{ }^{\circ} \mathrm{C}$ was higher than other groups, which contributed to a more wetting surface (Fig. 5a). High-resolution XPS data demonstrated that a large number of hydroxyl and carboxyl groups were generated on the GLC coating (Fig. 5b).

\subsection{Cellular Morphology and Cytology Test of RGD Peptides Modified GLC-C/C Composites}

Figure 6 shows the cellular morphology of MC3T3-E1 osteoblast-like cells, and they were well spread and in good status on the modified GLC coating. To assess cell adhesion and proliferation abilities, samples were seeded with MC3T3-E1 osteoblast-like cells and cultured for 1 week. Figure 7 shows the absorbance values of cells at day 1,3,5 and 7, respectively. GLC-RGD (RGD peptides modified GLC-C/C) had a significantly higher absorbance value than those of other samples from day 1 in the whole experiment.
The absorbance values of GLC-40 (GLC-C/C oxidized at $40{ }^{\circ} \mathrm{C}$ ) were higher than those of CLC (GLC-C/C) and C/C composites.

\section{Discussion}

RGD peptides were successfully immobilized on GLC coating with $\mathrm{C} / \mathrm{C}$ substrate. GLC coating was utilized to prevent carbon particles releasing from $\mathrm{C} / \mathrm{C}$ composites and create a uniform surface condition. RGD peptides enhanced the bioactivity of GLC coating.

GLC coating was constituted by graphite-like crystallites and $\mathrm{C} / \mathrm{C}$ composites consisted of carbon fibers and pyrolytic carbon. Both of the coating and substrate were pure carbon material. Though Raman spectra had shown their difference in microstructure, XPS data demonstrated that their surface chemical states were very similar. As we know, the improvement in surface wettability could improve the cell adhesion and biocompatibility [29]. The cytological experiments and contact angle measurement showed a similar result. The surfaces of both untreated and oxidized GLC coating were hydrophilic, and the

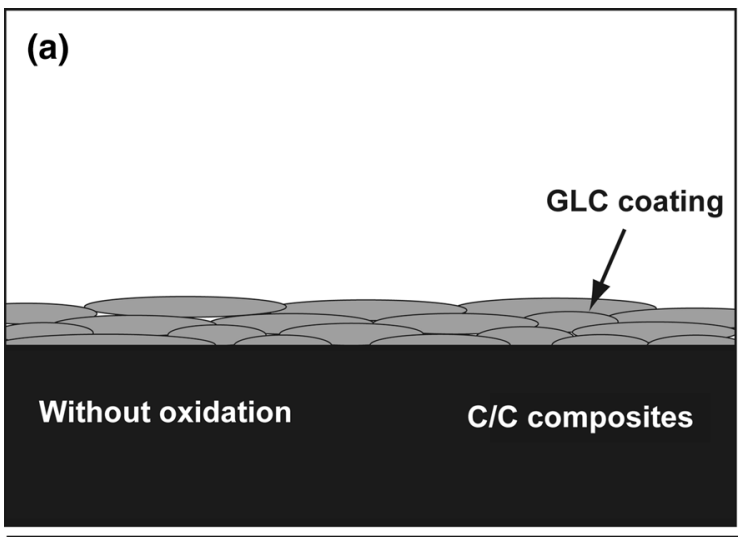

(c)

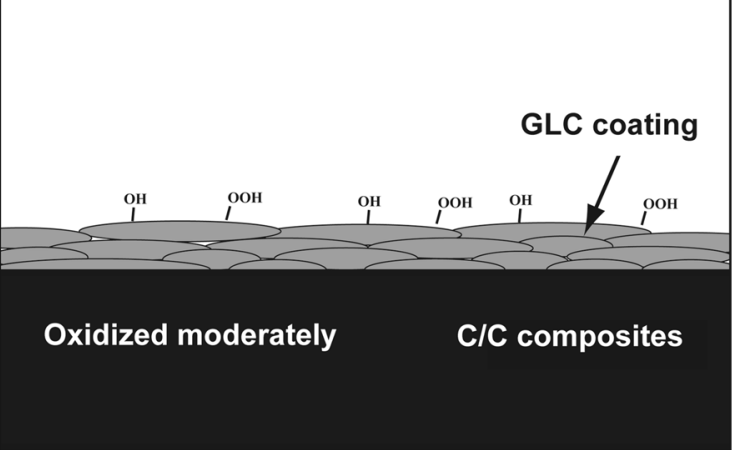

(b)

Oxidized at $30^{\circ} \mathrm{C}$

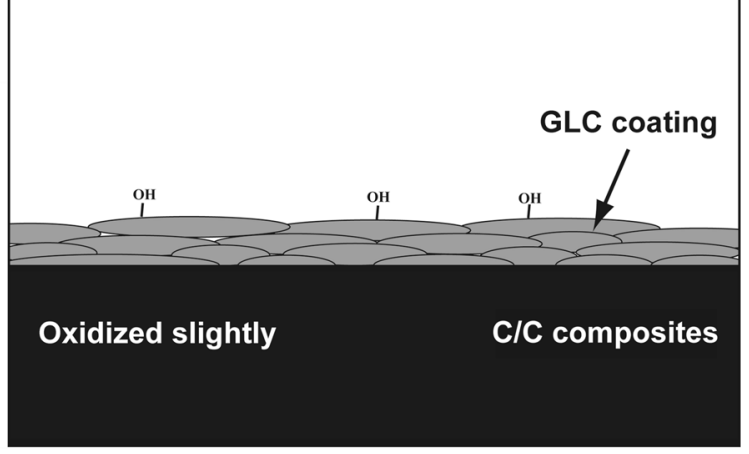

(d)

Oxidized over $50^{\circ} \mathrm{C}$

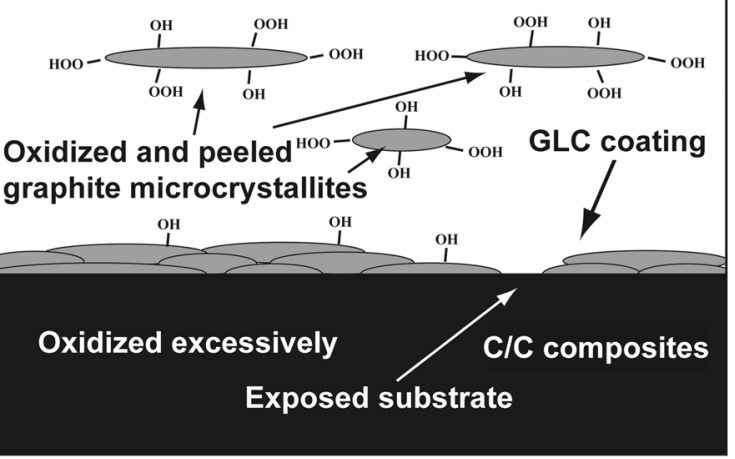

Fig. 8 Schematic diagram of GLC coating peeling at different oxidation temperatures 
biocompatibility of $\mathrm{C} / \mathrm{C}$ composites was improved. However, this improvement was still limited, when compared with RGD peptides immobilized sample.

To enhance the bioactivity of GLC coating without affecting its own functions, the suitable $\mathrm{H}_{2} \mathrm{O}_{2}$ modification temperature played key roles before RGD peptides immobilizing in this process. As we know, small graphitelike crystallites were adhered on the surface of $\mathrm{C} / \mathrm{C}$ composites during the deposition process and these crystallites constituted a completely GLC coating in an island growth mode (Fig. 8a). Though a small amount of oxygen-containing functional groups was formed on the surface of GLC-C/C, the modification level was minimal and no improvement in surface wettability was detected, when the oxidation temperature was $30^{\circ} \mathrm{C}$ (Fig. 8b). As the oxidation temperature increased to $40{ }^{\circ} \mathrm{C}$, a large number of hydroxyl and carboxyl groups were generated (Fig. 8c). However, the amount of these oxygen-containing functional groups was not checked as the oxidation temperature increased. This situation must be caused by peeling GLC coating and this peeling process may be similar to the preparation methods of graphite oxide and graphene oxide [30, 31].

Oxygen-containing functional groups were cross-linked to the topological defect areas of graphite-like crystallites in GLC coating firstly. Then, the interlayer spacing of graphite-like crystallites was increased and peeled off from GLC coating, when the oxidation temperature reached a certain level and combined with the influence of internal stress between crystallites (Fig. 8d). After that, oxidation cycle occurred repeatedly on the surface of newly exposed GLC coating until the $\mathrm{C} / \mathrm{C}$ substrate was exposed. Therefore, the wettability of GLC coating at $50{ }^{\circ} \mathrm{C}$ was as same as that of the untreated GLC coating. As the oxidation temperature continually increased, the rate of this oxidation and peeling process of GLC coating would be accelerated. Peeling off graphite-like crystallites resulted in a thickness difference in GLC coating and made it colorful under optical observation. In addition, D and $\mathrm{G}$ characteristic peaks of $\mathrm{C} / \mathrm{C}$ substrate were observed in the Raman spectra of GLC coating, which also reflected the thickness decrease in GLC coating.

\section{Conclusion}

RGD peptides were successfully immobilized on GLC coating with $\mathrm{C} / \mathrm{C}$ substrate. GLC coating was utilized to prevent carbon particles releasing from $\mathrm{C} / \mathrm{C}$ composites. Moderate $\mathrm{H}_{2} \mathrm{O}_{2}$ oxidation functionalized the GLC coating with generating oxygen-containing functional groups. The modified GLC coating with immobilized RGD peptides provided $\mathrm{C} / \mathrm{C}$ composites with a bioactive surface for cell adhesion and proliferation. It is anticipated that the bioactive molecules could be immobilized on the traditional amorphous carbon coating. The wear resistance of amorphous carbon coating and the bioactivity of bimolecular could be composed together. That will extend medical applications of $\mathrm{C} / \mathrm{C}$ composites.

Acknowledgements This work was supported by the National Natural Science Foundation of China under Grant Nos. 51202194 and 51221001, the Programme of Introducing Talents of Discipline to Universities ("111" project of China) under Grant No. B08040.

\section{References}

[1] B.D. Ratner, Biomaterials science: an introduction to materials in medicine, 2nd edn. (Elservier Pte Ltd, Amsterdam, 2004)

[2] J.L. Ely, M.R. Emken, J.A. Accuntius, D.S. Wilde, A.D. Haubold, R.B. More, J.C. Bokros, J. Heart Valve Dis. 7, 626 (1998)

[3] S.E. Rodil, R. Olivares, H. Arzate, S. Muhl, Diam. Relat. Mater. 12, 931 (2003)

[4] S. Logothetidis, Diam. Relat. Mater. 16, 1847 (2007)

[5] S.E. Rodil, R. Olivares, H. Arzate, S. Muhl, Top. Appl. Phys. 100, 55 (2006)

[6] R. Olivares, S.E. Rodil, H. Arzate, Diam. Relat. Mater. 16, 1858 (2007)

[7] N. More, C. Baquey, X. Barthe, F. Rouais, J. Rivel, M. Trinquecoste, A. Marchand, Biomaterials 9, 328 (1988)

[8] C. Baquey, L. Bordenave, N. More, J. Caix, B. Basse-Cathalinat, Biomaterials 10, 435 (1989)

[9] L.L. Zhang, H.J. Li, Q. Song, K.Z. Li, J.H. Lu, Y.L. Zhang, J. Hampshire, W. Li, Surf. Interface Anal. 46, 24 (2014)

[10] P. Chaudhary, T.C. Pesacreta, R.D.K. Misra, J. Biomed. Mater. Res. A 100, 3157 (2012)

[11] U. Hersel, C. Dahmen, H. Kessler, Biomaterials 24, 4385 (2003)

[12] K. Oya, Y. Tanaka, H. Saito, K. Kurashima, K. Nogi, H. Tsutsumi, Y. Tsutsumi, H.I. Doi, N. Nomura, T. Hanawa, Biomaterials 30, 1281 (2009)

[13] W.B. Tsai, Y.R. Chen, W.T. Li, J.Y. Lai, H.L. Liu, Carbohydr. Polym. 89, 379 (2012)

[14] M. Gabriel, G.P.V. Amerongen, V.W.M. Van Hinsbergh, A.V.V. Amerongen, A. Zentner, J. Biomat. Sci. Polym. 17, 567 (2006)

[15] C. Chollet, C. Chanseau, B. Brouillaud, M.C. Durrieu, Biomol. Eng. 24, 477 (2007)

[16] H.S. Seo, Y.M. Ko, J.W. Shim, Y.K. Lim, J.K. Kook, D.L. Cho, B.H. Kim, Appl. Surf. Sci. 257, 596 (2010)

[17] O. Akhavan, E. Ghaderi, Small 9, 3593 (2013)

[18] J.T. Robinson, S.M. Tabakman, Y.Y. Liang, H.L. Wang, H.S. Casalongue, D. Vinh, H.J. Dai, J. Am. Chem. Soc. 133, 6825 (2011)

[19] R.D.K. Misra, D. Depan, J.S. Shah, Acta Biomater. 8, 1908 (2012)

[20] S.H. Li, Z.G. Zheng, Q. Liu, J.R. de Wijn, K. de Groot, J. Biomed. Mater. Res. 40, 520 (1998)

[21] O. Akhavan, E. Ghaderi, A. Akhavan, Biomaterials 33, 8017 (2012)

[22] O. Akhavan, E. Ghaderi, H. Emamy, F. Akhavan, Carbon 54, 419 (2013)

[23] B. Girase, J.S. Shah, R.D.K. Misra, Adv. Eng. Mater. 14, 101 (2012)

[24] S. Cao, H.J. Li, K.Z. Li, J.H. Lu, L.L. Zhang, Appl. Surf. Sci. 347, 307 (2015)

[25] J.G. Zhao, K.Z. Li, H.J. Li, C. Wang, Carbon 44, 786 (2006) 
[26] Y.J. Wang, H.X. Li, L. Ji, F. Zhao, X.H. Liu, Q.H. Kong, Y.X. Wang, W.L. Quan, H.D. Zhou, J.M. Chen, J. Phys. D Appl. Phys. 43, 76 (2010)

[27] Y.J. Wang, H.X. Li, L. Ji, F. Zhao, Q.H. Kong, Y.X. Wang, X.H. Liu, W.L. Quan, H.D. Zhou, J.M. Chen, Surf. Coat. Technol. 205, 3058 (2011)
[28] S. Cao, H.J. Li, K.Z. Li, J.H. Lu, L.L. Zhang, J. Biomed. Mater. Res. A 104, 533 (2016)

[29] S.R. Paital, N.B. Dahotre, Mater. Sci. Eng., R 66, 1 (2009)

[30] C. Nethravathi, M. Rajamathi, Carbon 46, 1994 (2008)

[31] J. Chattopadhyay, A. Mukherjee, S. Chakraborty, J. Kang, P.J. Loos, K.F. Kelly, H.K. Schmidt, W.E. Billups, Carbon 47, 2945 (2009) 